\title{
Laryngealis szúkületek innovatív sebészi megoldásai újszülött- és csecsemőkorban
}

\author{
Bach Ádám dr. - Erdélyi Eszter dr. - Sztanó Balázs dr. \\ Tóbiás Zoltán dr. - Rovó László dr. \\ Szegedi Tudományegyetem, Általános Orvostudományi Kar, \\ Fül-Orr-Gégészeti és Fej-Nyaksebészeti Klinika, Szeged
}

\begin{abstract}
A veleszületett légúti szúkületek gyakran kombináltan jelentkeznek, és más szervrendszert is érintő kíséróbetegségekkel, illetve malformációkkal is társulhatnak. Figyelembe véve ezeket a tényezőket, illetve a csecsemőkori légút speciális anatómiáját és sérülékeny szöveteit, a felső légúti szúkületek sebészi kezelése újszülött- és csecsemőkorban igen nagy kihívást jelentő feladat, melynek célja a mihamarabbi definitív, stabil légút biztosítása a hangképzés és a nyelési funkció megőrzésével. A laryngomalacia, a hangszalagbénulás és a subglotticus stenosis együttesen a gége veleszületett rendellenességeinek megközelítóleg 90\%-áért felelős. A szerzők erre a három kórképre fókuszálva egy-egy eset kapcsán bemutatják a Szegedi Tudományegyetem Fül-Orr-Gégészeti és Fej-Nyaksebészeti Klinikáján múködő légútsebészeti munkacsoport által rutinszerúen alkalmazott innovatív sebészi módszereket. A bemutatott sebészeti megoldások egy lépésben, tracheostoma, sztentelés és graft beültetése nélkül azonnali stabil légutat biztosítanak jó hangminőséggel és nyelési funkcióval a supraglottis, a glottis és a subglottis dinamikus és statikus szúkületei esetén egyaránt.
\end{abstract}

Orv Hetil. 2021; 162(52): 2100-2106.

Kulcsszavak: hangszalagbénulás, laryngomalacia, subglotticus stenosis, 'slide' laryngotracheoplastica, endoszkópos arytenoid abdukciós lateropexia

\section{Innovative surgical solutions for laryngeal stenoses in newborns and infants}

Congenital airway stenoses occur frequently in combinations or may be associated with comorbidities and malformations affecting other organ systems. Considering these factors as well as the special anatomy and vulnerable tissues of the pediatric airway, surgical treatment in neonates and infants is an extremely challenging task. The ultimate goal of the management is to ensure a definitive and adequate airway as soon as possible with the preservation of voice and swallowing. Laryngomalacia, vocal cord palsy and subglottic stenosis together account for approximately $90 \%$ of congenital laryngeal disorders. Focusing on these three diseases, the authors - the airway surgery working group at the Department of Otolaryngology and Head and Neck Surgery, University of Szeged, Hungary - present their routinely applied innovative surgical strategies in connection with three cases. The presented 'one-step' surgical solutions provide immediate stable airway with good voice quality and swallowing function without tracheostomy, stenting, or graft implantation for both dynamic and static stenoses of the supraglottis, glottis, and subglottis.

Keywords: endoscopic arytenoid abduction lateropexy, laryngomalacia, slide laryngotracheoplasty, subglottic stenosis, vocal cord palsy

Bach Á, Erdélyi E, Sztanó B, Tóbiás Z, Rovó L. [Innovative surgical solutions for laryngeal stenoses in newborns and infants]. Orv Hetil. 2021; 162(52): 2100-2106.

(Beérkezett: 2021. május 6.; elfogadva: 2021. június 11.)

\section{Rövidítések}

EAAL = endoszkópos arytaenoid abdukciós lateropexia; ETGI $=($ endolaryngeal thread guide instrument $)$ endolaryngealis fonalvezető eszköz; SLtp = 'slide ' laryngotracheoplastica
A laryngotrachealis komplexum csecsemő- és gyermekkori szúkületei számos olyan veleszületett és szerzett kórképet foglalnak magukban, melyek potenciális veszélyeik miatt gyors és precíz diagnosztikát, illetve személy- 
re szabott, lehetőleg egy lépésben történő sebészi megoldást követelnek meg $[1,2]$. A légút fejlődési rendellenességei ritkák, pontos gyakoriságuk nem ismert, incidenciájuk 2-10/100 000 élveszülés intervallumra tehető [3]. A szerzett esetek száma az utóbbi évtizedekben növekvő tendenciát mutat a hosszan tartó intubáció elterjedése és a kis súlyú új- és koraszülöttek túlélési esélyeinek növekedése miatt. A szóban forgó kórképek az enyhe inspiratorikus stridortól kezdve az akut légzési elégtelenségig széles skálán mozgó panaszokat okozhatnak [4]. Habár a fóként az endoszkópos vizsgálatokra támaszkodó diagnosztikus lépések és kritériumok nemzetközi szinten is jól meghatározottak, a laryngotrachealis stenosisok menedzsmentjéból a mai napig hiányoznak a jól definiált sebészeti protokollok. A legtöbb ellátóhelyen a kezelési stratégia legalább annyira függ a légúti team tapasztalataitól, mint a csecsemó állapotától [5].

A régió szúkületeinek sebészi megoldása igen nagy kihívást jelent. Végső cél a definitív, stabil légút biztosítása, a hangképzés és a nyelési funkció megőrzésével. A veleszületett légúti szúkületek gyakran kombináltan jelentkeznek, és más szervrendszert érintő kísérőbetegségekkel, illetve malformációkkal is társulhatnak [6]. Figyelembe véve ezeket a tényezőket, illetve a csecsemókori légút speciális anatómiáját és sérülékeny szöveteit, a megfelelő sebészi beavatkozás megválasztása létfontosságú ebben a fiatal korosztályban. A csecsemók gyors fejlődési üteme miatt a laryngealis struktúrák posztoperatív stabilitása szintén kiemelt fontossággal bír a hosszú távú eredmények szempontjából.

Az elmúlt évtizedekben a légútsebészet komoly fejlődésen ment keresztül az új, innovatív mütéti technikák elterjedésével és az egyre fejlődő anesztéziai lehetőségek által [4]. A legtöbb esetben azonban még napjainkban is a sürgôsségi, elsődleges légútbiztosítási módszer a tracheotomia, annak minden komplikációjával, pszichés és pszichoszociális nehézségével együtt [7-9]. A laryngomalacia, a hangszalagbénulás és a subglotticus stenosis együttesen a gége veleszületett rendellenességeinek megközelítőleg 90\%-áért felelős [10]. Jelen munkánk célja, hogy egy-egy eset kapcsán illusztráljuk a Szegedi Tudományegyetem Fül-Orr-Gégészeti és Fej-Nyaksebészeti Klinikáján múködő légútsebészeti munkacsoport által rutinszerúen alkalmazott innovatív sebészi koncepciókat.

\section{Első eset}

A két hónapos csecsemő esetében alváskor jelentkező, testhelyzettől függő intenzitású horkolás és jelentős táplálási nehezítettség miatt indult kivizsgálás. A légúti status felmérése során ómega alakú epiglottist észleltünk, illetve belégzéskor az aryepiglotticus redők kifejezett obstrukciót okozó collapsusát tapasztaltuk (II-es típusú laryngomalacia). Ennek megfelelően aryepiglottoplastica mellett döntöttünk, amelyet intratrachealis narkózisban, ultrapulzációs $\mathrm{CO}_{2}$-lézerrel végeztünk el (1. ábra). A mindössze 15 perces beavatkozás során az ómega alakú epiglottis széli részének vaporizációja és az aryepiglotticus redők ékreszekciója történt. A mütétet követően a csecsemőt intubált állapotban a gyermek-intenzívosztályra adtuk át, ahol 2 órás obszervációt követően extubálást végeztek. A mütétet követő napon intenzív osztályos megfigyelés már nem volt indokolt. Eseménytelen obszervációt követóen a csecsemőt a 4. posztoperatív napon emittálták. Stridora ekkorra már lényegében megszűnt, ezzel párhuzamosan a csecsemő per os táplálhatósága is rendeződött.

\section{Második eset}

A 37. gestatiós hétre született újszülött esetében közvetlenül a születést követően inspiratorikus stridort észleltek. Per os táplálása nagymértékben akadályozott volt, emellett folyamatos oxigénszupplementációs igénye is fennállt. Az 5 napos korában végzett direkt endoszkópia során kétoldali gégefélbénulást észleltünk, paramedián
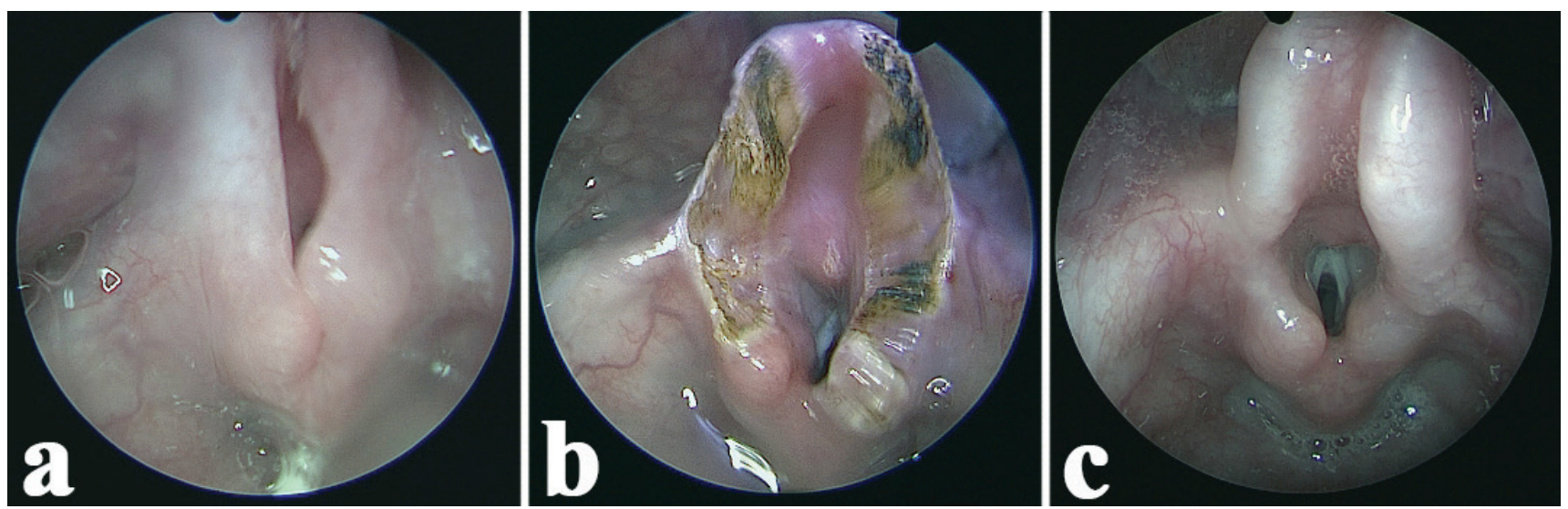

1. ábra

II-es típusú laryngomalacia műtéti megoldása: $\mathrm{CO}_{2}$-lézeres aryepiglottoplastica két hónapos csecsemő esetén (endoszkópos képek). a) Az aryepiglotticus redők jelentős collapsusa látható belégzéskor. A gégebemenet nehezen hozható látótérbe. b) Közvetlenül az epiglottis széli részének vaporizációja és az aryepiglotticus redők ékreszekciója után a hangszalagok láthatóvá válnak. A gégebemenet feltágul. c) 1 hónappal a mútét után a nyálkahártya teljes regenerációja látható. Belégzéskor dinamikus obstrukció nem észlelhető 


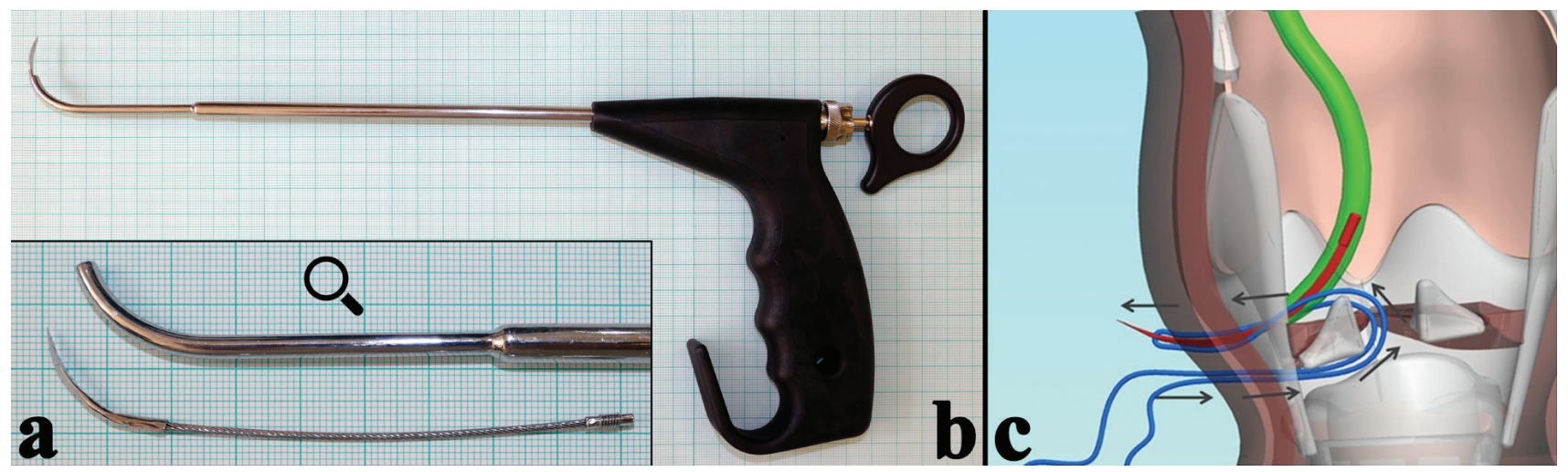

2. ábra

A csecsemók számára kialakított fonalvezető eszköz (endolaryngeal thread guide instrument, ETGI) és az endoszkópos arytaenoid abdukciós lateropexia (EAAL) sémás ábrája. a) Csecsemók számára kialakított tűvezető szár és tű (2,5-szeres nagyítás). b) Csecsemők számára kialakított endolaryngealis fonalvezető eszköz (túvezető szár és a markolat összeszerelve). c) A processus vocalis körül kialakított kettős öltés a kannaporcot maximálisan abdukált helyzetben rögzíti (sémás ábra, a gége hátsó nézetből)
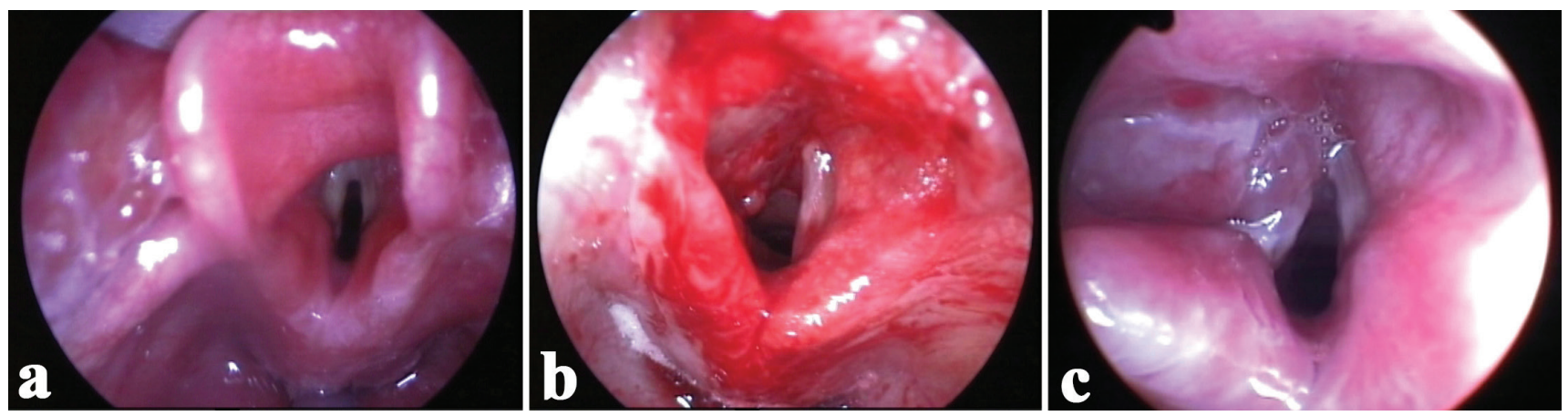

3. ábra

Bal oldali endoszkópos arytaenoid abdukciós lateropexia kétoldali hangszalagbénulásban szenvedő ötnapos újszülött esetén (endoszkópos képek). a) Endoszkópos vizsgálat során a hangszalagok sem abdukciós, sem addukciós mozgást nem mutatnak. A hangrés szúk. b) Bal oldali endoszkópos arytaenoid abdukciós lateropexia intraoperatív képe. c) Két héttel a beavatkozást követően kellóen tág hangrés látható. A bal gégefél lateralizált helyzetben

állású hangszalagokkal. 'Jet' narkózisban, szteroid- és antibiotikumvédelemben bal oldali endoszkópos arytaenoid abdukciós lateropexiát (EAAL) végeztünk, melynek során dupla, nem felszívódó fonallal a processus vocalist megkerülve a kannaporcot és ennek következtében a hangszalagot egy speciális fonalvezető eszköz (endolaryngeal thread guide instrument; ETGI; Mega Kft., Szeged) segítségével fiziológiás, maximálisan abdukált helyzetben rögzítettük (2. és 3. ábra) [11-13]. A gyermeket intubálva az újszülött-intenzívosztályra adtuk át. 5 napos intubációt követően szteroidbolus adása után az újszülöttet mútéti körülmények között - készen állva az esetleges azonnali légútbiztosításra - sikeresen extubáltuk. Ezt követően a stridor és az oxigénszupplementációs igény megszứnt. Az extubálást követő 3 . napon a nasogastricus tápszonda is eltávolításra került. Per os táplálása során aspiráció jelei nem mutatkoztak.

\section{Harmadik eset}

A közvetlenül a születése után intubált, 10 napos újszülött esetében direkt endoszkópia során körkörös, porcos, Cotton-Myer grade III subglotticus stenosis igazolódott, így külső feltárásból történő légúttágító mütét mellett döntöttünk [4]. 'Slide' laryngotracheoplastica (SLtp) során - bőséges laryngotrachealis mobilizációt követően - részleges elülső laryngofissiót és hátsó laminotomiát végzünk, majd a gyưrüporc ívét és részben a pajzsporcot is a trachea elülső falának interpozicionálásával tágítottuk fel (4. és 5. ábra) [14]. Az anasztomózis épségének érdekében a gyermek 7 napig intubálva maradt. A 8. posztoperatív napon történt extubálást követően a gyermek légzése akadálytalanná vált, ismételt légúttágító beavatkozás már nem volt indokolt.

\section{Megbeszélés}

Az áramlási ellenállás fordítottan arányos a légút sugarának negyedik hatványával [15]. Ennek megfelelően a légút sugarának felére csökkenése az ellenállás tizenhatszoros emelkedésével jár. Ez a szignifikánsan megnövekedett rezisztencia hatalmas terhet jelent az újszülöttekre, és jelentős mértékben gátolja a csecsemők fizikális és pszichés fejlődését. Ennek tükrében a hosszan tartó szoros obszerváció, illetve a „watch and wait policy” nem javasolt. Amennyiben a noninvazív pozitív nyomású lélegeztetés nem elégséges, intubáció, hosszabb távon pedig sebészeti beavatkozás szükséges. Mint urgens, 

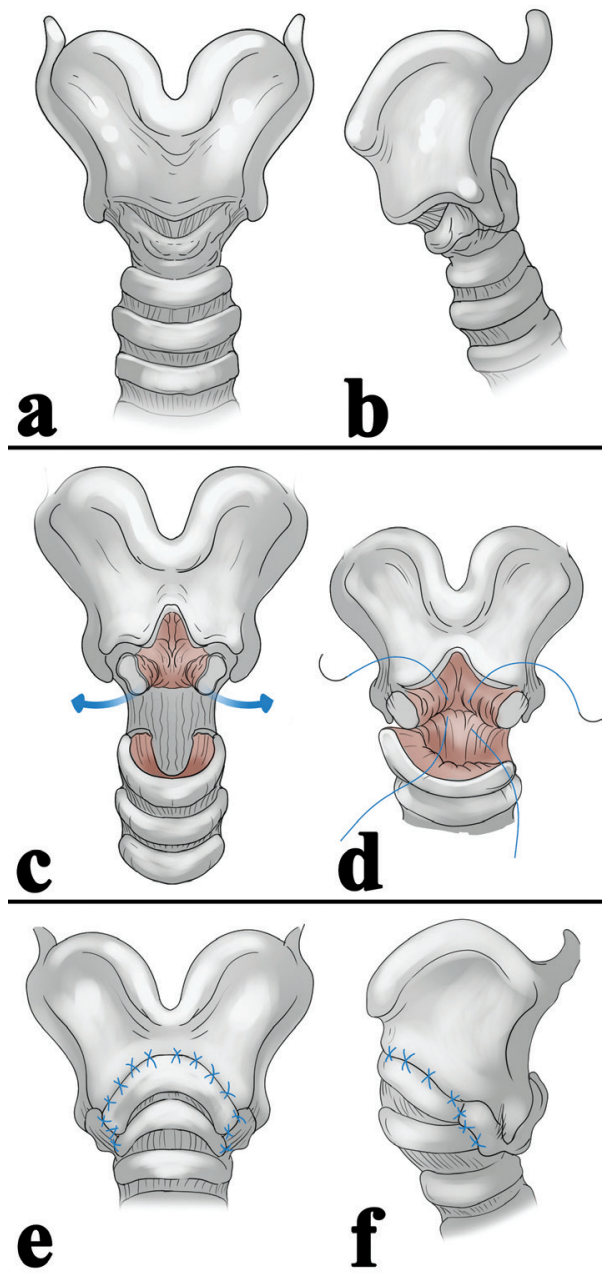

4. ábra A 'slide' laryngotracheoplastica sémás ábrája (elülső és oldalsó
nézet). a) és b) Subglotticus stenosis és hypoplasiás gyúrüporc
(preoperatív ábra). c) Parciális elülső laryngofissio az elülső
commissura megkímélésével. A trachea membranosus fala az
anasztomózis megfelelő illeszkedése érdekében a második por-
cig részben reszekált. d) Anasztomózis kialakítása a trachea a
gyứrú- és a pajzsporc között. Elsóként a hátsó falat rekonstruál-
juk. e) és f) A rekonstruált laryngotrachealis komplexum elülső
és oldalsó fala

életmentő beavatkozás, a tracheotomia érdemei vitathatatlanok, a mütét azonban együtt jár a hangminőség, a nyelési funkció és az életminőség drasztikus romlásával [16]. A definitív, egy lépésben végezhető sebészi megoldások megelőzhetik a következményes problémákat: a magas egészségügyi költségeket, a többszörös beavatkozásokat, a tracheamalacia kialakulását, a tracheostoma beszédfejlődésre káros hatásait, a rossz hangminőséget, az esetleges véletlen dekanülációt, a légút elzáródását és a krónikus légúti infekciók kialakulását [17-19].

Felső légúti szúkület gyanúja estén a direkt endoszkópos vizsgálat a diagnosztika legfőbb módszere, amely kisgyermekek esetén dominálóan általános érzéstelenítésben végezhető. Amennyiben a gyermek anamnézise, illetve tünetei szignifikáns légúti stenosis gyanúját vetik fel, intézetünkben rutinszerűen propofol indukálta narkózisban, spontán légzés és oxigén adása mellett flexibi-

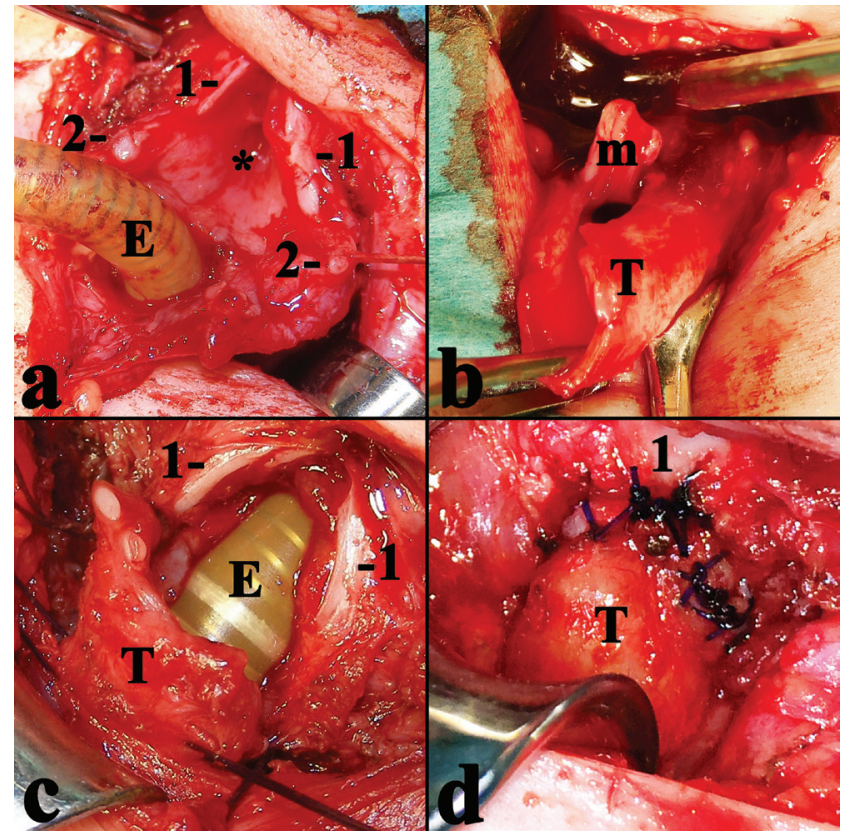

5. ábra A 'slide' laryngotracheoplastica tíznapos újszülött esetén (intra-
operatív képek). a) Parciális elülső laryngofissio a hangszalagok
szintjéig
1 = a pajzsporc lemezei a középvonalban szétválasztva; 2 = a
gyűrúporc íve a középvonalban szétválasztva; $\mathrm{E}=$ endotrachealis
tubus; *gégelumen
b) A mobilizált trachea $(\mathrm{T})$ membranosus részét $(\mathrm{m})$ a $2-3$. tra-
cheaporcig reszekáljuk a lehető legnagyobb lumen elérése érde-
kében. (Az endotrachealis tubus ideiglenesen eltávolítva.)
c) A hátsó fali varratsor elkészülte után transoralis intubációval
folytatjuk a mútétet.
$\mathrm{l}=$ a pajzsporc lemezei; $\mathrm{E}=$ endotrachealis tubus; T = trachea
d) Kétoldalról haladva kialakítjuk a pajzs-, a gyúrúporc és a tra-
chea közötti anasztomózist az elülső falon is.
$\mathrm{l}=$ a pajzsporc egyesített lemezei; T $=$ trachea

lis, majd merev eszközzel direkt laryngotracheoscopiát végzünk. 2014 és 2019 között 75 kisgyermeknél történt meg a fenti módszerrel a légúti status felmérése. Eredményeinket az 1 . táblázat foglalja össze.

Amennyiben a csecsemó nem szenved mentális retardációban és semmilyen más jelentős kísérő betegségben (fóként pulmonalis, cardialis vagy neurológiai abnormalitástól mentes), a légúti szúkületeket célszerú egy lépésben, tracheostoma kialakítása nélkül megoldani. Kritikus fontosságú, hogy a hosszú távon sikeres légúti beavatkozás legnagyobb esélye az elsődleges sebészeti beavatkozás idején van [20]. Ennek megfelelően a többszöri, nem megfelelően kiválasztott légúti mútétek elkerülése létfontosságú. A minimálisan invazív endoszkópos beavatkozások előnyben részesítendők, amennyiben azokkal definitív, stabil légút biztosítható. Az endoszkópos beavatkozások sikertelensége esetén azonban azok ismétlése helyett külső feltárásból végzett mútét mérlegelése javasolt, még annak tudatában is, hogy ezek a beavatkozások szignifikánsan nagyobb terheléssel és morbiditással járnak.

A leggyakoribb, dyspnoét okozó congenitalis betegség a laryngomalacia, mely a supraglotticus struktúrák dinamikus és passzív összeesésével járó szerkezeti és 
1. táblázat $\mid$ Felső légúti szúkület gyanúja miatt végzett direkt laryngotracheoscopia eredményei, illetve az alkalmazott mútéti terápia. További 17 gyermeknél nem észleltünk mütéti beavatkozást igénylő légúti szúkületet

\begin{tabular}{|c|c|c|c|c|}
\hline \multirow[t]{2}{*}{ Diagnózis } & \multirow[t]{2}{*}{ Laryngomalacia } & Kétoldali & Subglotticus/trachea stenosis & \multirow[t]{2}{*}{ Laryngealis web } \\
\hline & & \multicolumn{2}{|l|}{ hangszalagbénulás } & \\
\hline Esetszám & 21 & 21 & 15 & 1 \\
\hline \multirow[t]{2}{*}{ Beavatkozás } & $\mathrm{CO}_{2}$-lézeres & \multirow[t]{2}{*}{ Féloldali EAAL } & CTR, tracheareszekció, & $\mathrm{CO}_{2}$-lézeres \\
\hline & supraglottoplastica & & SLtp & reszekció \\
\hline
\end{tabular}

$\mathrm{CTR}=$ cricotrachealis reszekció; EAAL = endoszkópos arytaenoid abdukciós lateropexia; SLtp = 'slide' laryngotracheoplastica

funkcionális elváltozás [21-24]. Az esetek megközelítőleg 15\%-ában a laryngomalacia súlyos dyspnoét, obstruktív alvási apnoét és a fizikális fejlődést szignifikánsan befolyásoló táplálási nehezítettséget okoz, melyek miatt elkerülhetetlen a sebészi beavatkozás. A nemzetközileg elfogadott megoldás napjainkban az endoszkópos supraglottoplastica, melynek alapjait az 1980-as években fektették le. A mútét elvégzéséhez a mai napig több típusú eszköz használatos [25]. A „hideg” mikrosebészeti múszerekkel történő beavatkozás és a $\mathrm{CO}_{2}$-lézer használata egyaránt elfogadott, ezek mellett ritkábban alkalmazott módszer a microdebrider is. A lézer használatát 1985-ben Seid és mtsai vezették be a megrövidült aryepiglotticus redők reszekciójára [26]. Hazánkban 2002ben Katona Gábor és mtsai elsőként végeztek hidegeszközös supraglottoplasticát csecsemón [27]. A lézer vitathatatlan előnye, hogy a jól kontrollált vágás mellett alkalmas vérzéscsillapításra is. A technika ellenzői ezzel szemben a potenciális hókárosodás veszélyeire (fokozott ödémaképződés, fájdalom, dysphagia, hegesedés) hívják fel a figyelmet. Ezek a hátrányok azonban kiküszöbölhetők, amennyiben a folyamatos energiájú $\mathrm{CO}_{2}$-lézer helyett ultrapulzációs lézert használunk, melynek energiaprofilja eltér a hagyományos $\mathrm{CO}_{2}$-lézerétől. $\mathrm{Az}$ ultrapulzációs módra jellemzô, hogy az energiát a lézer háromszögimpulzusokban adja le, így az impulzusok közötti időben a szöveteknek van idejük lehúlni. Ebből adódóan kisebb az oldalhő mértéke, csökken a szöveti károsodás, minimalizálható az ödéma, így a gyógyulás idôtartama is lerövidül [28]. A morfológiai variánsoknak megfelelően a mútéti beavatkozások a következők lehetnek [29]: Enyhe esetben (I. típus: az arytaenoid, valamint a corniculataporcok anterocaudalis collapsusa) az aryepiglotticus redőt a cartilago corniculatumtól indulva az epiglottis széléig haladva vaporizáljuk. A II. típus esetében (a rövid aryepiglotticus redók prolapsusa) az ómega alakú epiglottis széli részét vaporalizáljuk, és az aryepigloticus redőkön ékreszekciót végzünk ( 1 . ábra). Súlyos esetben (III. típus: az epiglottis posterocaudalis suctiója) a laza epiglottison a lingualis felszínen és a nyelvgyöki tonsillán is nagy hegesedést okozó sebzést ejtünk, és az epiglottist a nyelvgyökhöz öltjük. A beavatkozást követóen a gyermekek 1-2 órán keresztül intubálva maradnak. Az intenzív osztályt 24 órán belül elhagyhatják [28].
A hangszalagbénulás a gége második leggyakoribb fejlődési rendellenessége [30]. A féloldali esetek újszülöttés csecsemőkorban túlnyomó többségükben nem igényelnek kezelést, természetüknél fogva gyakran diagnosztizálatlanok maradnak [31]. Kétoldali hangszalagbénulás esetén azonban a következményes súlyos fokú dyspnoe azonnali beavatkozást követel [32]. Az irodalomban számos, külső feltárásból (arytaenoidectomia, arytaenoidopexia, arytaenoidectomia a hangszalagok öltéssel történő lateralizálásával, a hátsó commissura tágítása porcgraft beültetésével) és endoszkópos úton $\left(\mathrm{CO}_{2}\right.$-lézeres arytaenoidectomia, lézeres posterior cordotomia, hangszalag-lateralizáció) végzett hangréstágító mútét ismert [33]. Ezek általában a glottis struktúráinak változó mértékú reszekciójával járnak. A laryngomalacia sebészetéhez képest az alkalmazott sebészi megoldások heterogenitása szembeötlő. Az újszülöttkori hangszalagbénulások $\mathrm{kb}$. $60 \%$-a részben vagy teljesen reverzibilis [34]. A bénulás észlelésekor azonban a prognózis nem jósolható meg, az esetleges regeneráció heteket, hónapokat vehet igénybe. Ennek megfelelően célszerü minimálisan invazív, a gégestruktúrákban irreverzibilis változásokat nem okozó megoldást választani a dyspnoe megszüntetésére. Az optimális sebészi beavatkozás reverzibilis, kis mútéti terheléssel jár, gyors, azonnal megfelelő tágasságú légutat biztosít a hangképzési és a nyelési funkció megőrzésével. Ezeket az elvárásokat a bemutatott EAAL maradéktalanul teljesíti. Kiemelendő, hogy a hangszalagok megfelelő abdukciós mozgásainak visszatérésekor a lateralizáló öltések egyszerúen eltávolíthatók. Az EAAL a hangszalagok pseudoparesisekor (mechanikai fixációjakor), a hátsó commissurahegesedés esetén is jól alkalmazható technika a kannaporcok ideiglenes rögzítésére. A cricoarytaenoid ízületet fixáló hegek oldását követôen a mobilizált kannaporcok kétoldali lateralizációjával megelőzhető a hegek ismételt kialakulása $[35,36]$. Amint a hátsó commissura területén a reepithelisatio lezajlott, a lateralizáló öltések ugyancsak eltávolíthatók.

Subglotticus stenosisról beszélünk, amennyiben a subglottis átméróje újszülött esetében kevesebb mint 4 mm, koraszülött esetében kevesebb mint $3 \mathrm{~mm}$ [4]. A laryngomalacia és a hangszalagbénulás után ez a gége harmadik leggyakoribb fejlődési rendellenessége, azonban ez a kórkép a csecsemőkori tracheotomia leggyako- 
ribb oka [37, 38]. A minimálisan invazív endoszkópos technikák (hidegeszközzel vagy lézerrel történő hegkimetszés, ballonos dilatáció, lokális szteroid- és/vagy mitomicininjekció) csak kis fokú szúkuületek esetén adnak definitív megoldást. Emellett a fenti beavatkozások növelik az esetleges urgens légúti beavatkozások incidenciáját, és késleltethetik a probléma végleges megoldását [39, 40]. Mindemellett a minimálisan invazív technikák eredményessége fordítottan arányos a subglotticus stenosis súlyossági fokával [41-43]. Amennyiben porcos vagy kombinált laryngotrachealis stenosist észlelünk, vagy a szúkült szakasz $1 \mathrm{~cm}$-nél hosszabb, illetve a trachea membranosus fala is érintett, a restenosis magas valószínúsége miatt endoszkópos beavatkozások nem javasoltak. A laryngotrachealis rekonstrukció és a cricotrachealis szegment reszekciója évtizedek óta alkalmazott, jól bevált mútéti módszerek megbízható, hosszú távú eredményekkel. Ezek a komplex beavatkozások azonban nagy méretű reszekciót, bordaporcgrafttal történő légúti tágítást, sztentbehelyezést és tracheotomiát igényelnek $[44,45]$. Ezeket a hátrányokat az intézetünkben kialakított SLtp képes áthidalni. A 'slide' tracheaplastica elvének módosításával a fiziológiásnál tágabb subglotticus tér, illetve jó vérellátású, stabil szerkezetű laryngotrachealis anasztomózis hozható létre. Az anasztomózis szintjében ép nyálkahártyával borított és porctámasztékkal rendelkező stabil varratsor alakítható ki, mely azonnal megfelelően tág, stabil légúti keresztmetszetet biztosít, lerövidíti a sebgyógyulást, csökkenti a granulációképződés lehetőségét, és szükségtelenné teszi az ideiglenes tracheostomát és a hosszú ideig tartó sztentelést [14]. A mútéttel elérhető, fiziológiásnál tágabb subglotticus tér esetleges enyhe fokú restenosis esetén is megfelelő tágasságú légutat biztosít.

\section{Következtetés}

A bemutatott sebészi módszerek egy lépésben, tracheostoma, sztentelés és graft beültetése nélkül azonnali stabil légutat biztosítanak jó hangminőséggel és nyelési funkcióval a supraglottis, a glottis és a subglottis dinamikus és statikus szúkuületei esetén egyaránt. Alkalmazásukkal elérhető, hogy a ritka, ám az életminőségre igen súlyos hatást gyakorló felső légúti szúkületekben szenvedő gyermekek teljes életet éljenek, illetve fizikális és pszichés fejlődésük a kortársaikkal azonos ütemú legyen. A veszélyeztetett légút menedzsmentje komplex feladat, amely csak a legmagasabb szintû személyi és technikai feltételek együttes teljesülése mellett lehet sikeres, ezért minden, légúti szúkületben szenvedő gyermek kezelése erre kialakított centrumban kell hogy történjen!

Anyagi támogatás: A közlemény megírása, illetve a kapcsolódó kutatómunka anyagi támogatásban nem részesült.
Szerzői munkamegosztás: B. Á.: A kézirat megszövegezése, irodalmi áttekintés, mútétek elvégzése. E. E.: Irodalmi áttekintés, mütétek dokumentálása. Sz. B.: Szakmai véleményezés és tanácsadás, mütétek elvégzése. T. Z.: Irodalmi áttekintés, műtétek dokumentálása, az illusztrációk elkészítése. R. L.: Szakmai véleményezés és tanácsadás, mütétek elvégzése és kifejlesztése. A cikk végleges változatát valamennyi szerző elolvasta és jóváhagyta.

Érdekeltségek: A szerzőknek nincsenek érdekeltségeik.

\section{Irodalom}

[1] Holinger PH, Johnson KC, Schhiller F. Congenital anomalies of the larynx. Ann Otol Rhinol Laryngol. 1954; 63: 581-606.

[2] Redondo-Sedano J, Antón-Pacheco JL, Valverde RM, et al. Laryngeal stenosis in children: types, grades and treatment strategies. J Pediatr Surg. 2019; 54: 1933-1937.

[3] Daniel SJ. The upper airway: congenital malformations. Pediatr Respir Rev. 2006; 7(Suppl 1) 260-263.

[4] Monnier P. Pediatric airway surgery. Management of laryngotracheal stenosis in infants and children. Springer, New York, NY, 2011 .

[5] Landsman JS, Werkhaven EA, Motoyama K. Anaesthesia for pediatric otorhinolaringologic surgey. In: Davis PJ, Cladis FP, Motoyama EK. (eds.) Smith's anesthesia for infants and children. 8th ed. Mosby, St. Louis, MO, 2011; pp. 786-820.

[6] Friedman EM, Vastola AP, McGill TJ, et al. Chronic pediatric stridor: etiology and outcome. Laryngoscope 1990; 100: 277280.

[7] Pandian V, Garg V, Antar R, et al. Discharge education and care giver coping of pediatric patients with a tracheostomy: systematic review. ORL Head Neck Nurs. 2016; 34: 17-18., 20-27.

[8] Nakarada-Kordic I, Patterson N, Wrapson J, et al. A systematic review of patient and caregiver experiences with a tracheostomy. Patient 2018; 11: 175-191.

[9] Flynn AP, Carter B, Bray L, et al. Parents' experiences and views of caring for a child with a tracheostomy: a literature review. Int J Pediatr Otorhinolaryngol. 2013; 77: 1630-1634.

[10] Sichel JY, Dangoor E. Eliashar R, et al. Management of congenital laryngeal malformations. Am J Otolaryngol. 2000; 21 : 22-30.

[11] Rovó L, Madani S, Sztanó B, et al. A new thread guide instrument for endoscopic arytenoid lateropexy. Laryngoscope 2010; 120: 2002-2007.

[12] Madani S, Bach Á, Matievics V. et al. A new solution for neonatal bilateral vocal cord paralysis: endoscopic arytenoid abduction lateropexy. Laryngoscope 2017, 127: 1608-1614.

[13] Sztanó B, Bach Á, Matievics V, et al. Endoscopic arytenoid abduction lateropexy for the treatment of neonatal bilateral vocal cord paralysis - long-term results. Int J Pediatr Otorhinolaryngol. 2019; 119: 147-150.

[14] Rovó L, Erdélyi E, Tóbiás Z, et al. Slide laryngotracheoplasty for congenital subglottic stenosis in newborns and infants. Laryngoscope 2020; 130: E199-E205.

[15] Sutera, SP, Skalak R. The history of Poiseuille's law. Annu Rev Fluid Mechan. 1993; 25: 1-19.

[16] Woliansky J, Paddle P, Phyland D. Laryngotracheal stenosis management: a 16-year experience. Ear Nose Throat J. 2021; 100: 360-367.

[17] Gelbard A, Francis DO, Sandulache VC, et al. Causes and consequences of adult laryngotracheal stenosis. Laryngoscope 2015; 125: 1137-1143.

[18] Ciccone AM, De Giacomo T, Venuta F, et al. Operative and nonoperative treatment of benign subglottic laryngotracheal stenosis. Eur J Cardiothorac Surg. 2004; 26: 818-822. 
[19] Zias N, Chroneou A, Tabba MK, et al. Post tracheostomy and post intubation tracheal stenosis: report of 31 cases and review of the literature. BMC Pulm Med. 2008; 8: 18.

[20] Bailey M, Hoeve H, Monnier P. Paediatric laryngotracheal stenosis: a consensus paper from three European centers. Eur Arch Otorhinolaryngol. 2003; 260: 118-123.

[21] Zoumalan R, Maddalozzo J, Holinger LD. Etiology of stridor in infants. Ann Otol Rhinol Laryngol. 2007; 116: 329-334.

[22] Olney DR, Greinwald JH Jr., Smith RJ, et al. Laryngomalacia and its treatment. Laryngoscope 1999; 109: 1770-1775.

[23] Roger G, Denoyelle F, Triglia JM, et al. Severe laryngomalacia: surgical indications and results in 115 patients. Laryngoscope 1995; 105: 1111-1117.

[24] Thompson DM. Abnormal sensorimotor integrative function of the larynx in congenital laryngomalacia: a new theory of etiology. Laryngoscope 2007; 117(Suppl 114): 1-33.

[25] Bedwell J, Zalzal G. Laryngomalacia. Semin Pediatr Surg. 2016; 25: 119-122.

[26] Seid AB, Park SM, Kearns MJ, et al. Laser division of the aryepiglottic folds for severe laryngomalacia. Int J Pediatr Otorhinolaryngol. 1985; 10: 153-158.

[27] Katona G, Benedek P, Csákányi Zs, et al. Aryepiglottoplasty: the surgical management of the laryngomalacia. [Aryepiglottoplasztika: a laryngomalacia mútéti kezelése.] Fül-Orr-Gégegyógyászat 2002; 48: 79-83. [Hungarian]

[28] Tóbiás Z, Pálinkó P, Sztanó B, et al. Endoscopic ultra dream pulse laser surgery of laryngomalacia. Our experiences gained during the introduction of the method in Hungary. [A laryngomalacia endoszkópos ultrapulzációs-lézeres (ultra dream pulse) sebészete. A módszer hazai bevezetése során szerzett tapasztalataink.] Orv Hetil. 2017; 158: 1288-1292. [Hungarian]

[29] Simons JP, Greenberg LL, Mehta DK, et al. Laryngomalacia and swallowing function in children. Laryngoscope 2016; 126: 478484.

[30] Daya H, Hosni A, Bejar-Solar I, et al. Pediatric vocal fold paralysis: a long-term retrospective study. Arch Otolaryngol Head Neck Surg. 2000; 126: 21-25.

[31] Setlur J, Hartnick CJ. Management of unilateral true vocal cord paralysis in children. Curr Opin Otolaryngol Head Neck Surg. 2012; 20: 497-501.

[32] Belafsky PC. Bilateral vocal fold immobility. Curr Opin Otolaryngol Head Neck Surg. 2011; 19: 415.

[33] Sapundzhiev N, Lichtenberger G, Eckel HE, et al. Surgery of adult bilateral vocal fold paralysis in adduction: history and trends. Eur Arch Otorhinolaryngol. 2008; 265: 1501-1514.
[34] Jomah M, Jeffery C, Campbell S, et al. Spontaneous recovery of bilateral congenital idiopathic laryngeal paralysis: systematic non-meta-analytical review. Int J Pediatr Otorhinolaryngol. 2015; 79: 202-209.

[35] Sztanó B, Szakács L, Madani S, et al. Comparison of endoscopic techniques designed for posterior glottic stenosis - a cadaver morphometric study. Laryngoscope 2014; 124: 705-710.

[36] Palinko D, Matievics V, Szegesdi I, et al. Minimally invasive endoscopic treatment for pediatric combined high grade stenosis as a laryngeal manifestation of epidermolysis bullosa. Int J Pediatr Otorhinolaryngol. 2017; 92: 126-129.

[37] Holinger PH, Johnson KC, Schhiller F. Congenital anomalies of larynx. Ann Otol Rhinol Laryngol. 1954; 63: 581-606.

[38] Tucker GF, Ossoff RH, Newman AN, et al. Histopathology of congenital subglottic stenosis. Laryngoscope 1979; 89: 866877.

[39] Gadkaree SK, Pandian V, Best S, et al. Laryngotracheal stenosis: risk factors for tracheostomy dependence and dilation interval. Otolaryngol Head Neck Surg. 2017; 156: 321-328.

[40] Hseu AF, Benninger MS, Haffey TM, et al. Subglottic stenosis: a ten-year review of treatment outcomes. Laryngoscope 2014; 124: 736-741.

[41] Maresh A, Preciado DA, O'Connell AP, et al. A comparative analysis of open surgery $v s$ endoscopic balloon dilation for pediatric subglottic stenosis. JAMA Otolaryngol Head Neck Surg. 2014; 140: 901-905.

[42] Quesnel AM, Lee GS, Nuss RC, et al. Minimally invasive endoscopic management of subglottic stenosis in children: success and failure. Int J Pediatr Otorhinolaryngol. 2011; 75: 652-656.

[43] Chen C, Ni WH, Tian TL, et al. The outcomes of endoscopic management in young children with subglottic stenosis. Int $\mathrm{J}$ Pediatr Otorhinolaryngol. 2017; 99: 141-145.

[44] Jefferson ND, Cohen AP, Rutter MJ. Subglottic stenosis. Semin Pediatr Surg. 2016; 25: 138-143.

[45] Jaquet Y, Lang F, Pilloud R, et al. Partial cricotracheal resection for pediatric subglottic stenosis: long-term outcome in $57 \mathrm{pa}-$ tients. J Thorac Cardiovasc Surg. 2005; 130: 726-732.

(Bach Ádám dr., Szeged, Tisza Lajos krt. 111., 6725 e-mail: bach.adam@med.u-szeged.hu)

A cikk a Creative Commons Attribution 4.0 International License (https://creativecommons.org/licenses/by/4.0/) feltételei szerint publikált Open Access közlemény, melynek szellemében a cikk bármilyen médiumban szabadon felhasználható, megosztható és újraközölhető, feltéve, hogy az eredeti szerző és a közlés helye, illetve a CC License linkje és az esetlegesen végrehajtott módositások feltüntetésre kerülnek. (SID_1) 